\title{
CYRILO-METODSKÁ TRADÍCIA V LITERATÚRE PRE DETI A MLÁDEŽ V PREDUMELECKOM OBDOBÍ (ČÍTANKA, NÁRODNIE SPIEVANKY, SLOVENSKÁ ČÍTANKA)
}

\author{
Cyrillo-Methodian Tradition in Literature for Children and Young Adults \\ in the Pre-artistic Period \\ (Čítanka, Národnie spievanky, Slovenská čítanka)
}

\author{
Martina Petríková
}

DOI: 10.17846/CL.2021.14.1.113-122

\begin{abstract}
PETRÍKOVÁ, Martina. Cyrillo-Methodian Tradition in Literature for Children and Young Adults in the Pre-artistic Period (Č́tanka, Národnie spievanky, Slovenská čitanka). The study focuses on the Cyrillo-Methodian references in literature for children and young adults of the pre-artistic period. The works are studied within the context of (non-intentional $\rightarrow$ intentional) literature for children and young adults which are part of Enlightenment educational literature and literature of the Matica Slovenská period, seeking the thematic connections with the life and work of missionaries Cyril and Methodius and finding out how the editors of the works connected the texts with the Great Moravian period (for example in note-taking apparatus). The most important works of Enlightenment educational literature are studied (Č́tanka, Národnie spievanky by Ján Kollár) and literature for children and young adults of the Matica Slovenská period (Slovenská cítanka by Emil Černý). Literature for children and young adult of the Štúr period is also considered, since according to O. Sliacky (2013), the members of the Štúr's circle authorized Emil Černý to arrange a literary anthology which contained literary texts from the Romantic period.
\end{abstract}

Keyword: Cyrillo-Methodian tradition, literature for children and young adults in the preartistic period, Čítanka, Národnie spievanky, Slovenská čitanka

Kultúrnym odkazom vierozvestcov Cyrila a Metoda, ktorí pôsobili na Vel'kej Morave, sa inšpirovala aj neintencionálna $\rightarrow$ intencionálna literatúra pre deti a mládež predovšetkým $v$ niektorých periódach jej literárnohistorického vývinu.

Počiatky slovenskej literatúry pre deti a mládež siahajú do konca 18. storočia a spájajú sa $s$ úsilím osvietencov pozdvihnút vzdelanostnú úroveň národa. $\mathrm{V}$ tomto čase sa prostredníctvom tzv. Ratio educationis uskutočňuje reforma školstva, ktorá zdôrazňuje požiadavku všeobecného vzdelania. V predosvietenskom období boli súčastou školskej literatúry šlabikáre a katechizmy, a preto bolo potrebné budovat adekvátny učebnicový fond zreformovaného školského systému. Klúčovým dielom osvietenskej školskej literatúry sa stala Č́tanka Jána Kollára z roku 1825.

Peter Podolan $(2011,39)$ v štúdii Krátičká známost vlasti národu Slowanského charakterizuje rovnomenný Kollárov text, publikovaný v Č́tanke (1825) a neskôr v podobe výňatku (1844), ako „syntetický derivát základných znalostí o Slovanoch a slovanskom svete“. Upozorňuje však, že výraz slovanský z názvu kapitoly nemožno stotožnit s výrazom slovenský, ktorý sa vztahuje skôr na názov celého diela (Č́tanka anebo Kniha $k$ čitaní pro mládež ve školách slovanských $v$ mèstech 
a v dědinách). Ján Kollár pri vymedzení látky diela odkazuje na Uhorské královstvo, ale aj na dejiny Slovákov a jazykom textov sa stane modernizovaná biblická čeština s početnými slovakizmami, kedže ju považuje za vhodnú predovšetkým pre slovenskú mládež (Podolan 2011, 42, 44 - 45). Podla Jána Kollára sa má vzdelávanie detí a mládeže zo slovanských krajov uskutočňovat v slovanskom jazyku (porovnaj Kollárov návrh na reorganizáciu školstva, Ivantyšynová - Podolan Viršinská 2013, 44).

Kollárova Čítanka bola vyvrcholením osvietenských pedagogických úsilí. Už Samuel Tešedík v článku Môj názor na školskú učebnicu pre väčšie prakticko-ekonomické školy (1793) predložil projekt knihy, ktorá by bola školskou učebnicou a zároveň ludovýchovnou príručkou. Encyklopedickú príručku sa pokúsil vytvorit aj Martin Hamaliar (1750 - 1812). Ostala v rukopise Knihy školní k čítaní pro mládež v školách evanjelických, městečkách a dědinách, no stala sa východiskom pre vytvorenie encyklopedickej učebnice. Jej redaktorom sa stal Ján Kollár na žiadost’ Adama Dávida Lovicha a Pavla Jozeffyho (Brtáň 2000; Kollár 1972; Podolan 2011, 41; Sliacky 2007, 18n., 221).

V Předmluwe Čítanky (1825) jej zostavovatel’ uvádza, „Že sme w přjtomném djle nowěgšj prawopjsebnosti užili, gistě nám nikdo za zlé mjti nebude, kdo důkladnau známost našj řeči má; nechat mládež zawčasu př̀iwyká i ku prostěgšjmu a prawidelněgšjmu psánj“ (Kollár 1825, 3n.), resp. na inom mieste odporúča „wychowáwatelim a učiteli̛m slowenským“ (Kollár 1825, 4) vybrané pedagogické diela, ktoré možno získat v Pešti, Prešporku a Prahe a medzi ktoré patria aj knihy slovenských, či širšie, slovanských vzdelancov (A. Bernoláka, D. Lehockého, J. Palkoviča, B. Tablica a dalších). Zdôraznením výrazov slovenský a slovanský možno odhalit aj Kollárov záujem o slovanskú, užšie, slovenskú minulost’ a o cyrilo-metodskú tradíciu, aj ked’ sa o nej v Čítanke zmieňuje len okrajovo. V XV. kapitole Čítanky, v texte Krátičká známost národu Slowanského, ponúka vedomosti o „Slowanskom“(Kollár 1825) národe, prináša jeho „jazykovú“ (Podolan 2011, 45) charakteristiku, ale informuje aj o Slovákoch v slovanskom kontexte, o početnosti a geografii Slovanov (zaujímavé je ich spojenie s priestorom "při Tatrách, nad Dunagem“, ktoré sa neskôr stanú romantickými symbolmi slovenského národa; Podolan $(2011,46)$ pritom zdôrazňuje, že Kollár v druhom vydaní Čítanky spája pomenovanie Tatier s územím Slovákov, a nie so širším územným celkom), o ich pôvode, o pomenovaní Slovan, Slovák a ich pôvode ${ }^{1}$, ba i o hodnovernosti jednotlivých hypotéz pomenovania. ${ }^{2}$ Prináša poznatky o pomenovaní panovníkov, o mravoch a zvykoch Slovanov ${ }^{3}$, o pohanských božstvách, ale aj o krestanskom náboženstve a historicko-geografických súvislostiach jeho prijatia, či jeho šírení, o ostatných náboženstvách Slovanov, ba aj o slovanskej reči a jej „nářčcj “" (Kollár 1825, 205), o geograficko-historických údajoch týkajúcich sa Slovanov: mestá, hlavné mestá, rieky, horstvá, významní Slovania a Slovanky či rodiny/rody. ${ }^{4}$

1 „Odkud pochádzj to gméno Slaw, Slawjn, Slowák, Slowan? Nekteřj učenj ge odwodzugj od Slowo, gakoby lidé gednoho slowa a gazyka, kteřj soběwespolek rozuměgj; ginj ge odvozugj od S lá wa, sla wný a slow ú $n y ́$, proto že naši predkové slawné skutky činili a swým bogovánjm sláwu sobě zpưsobili, a tento počátek gména gest hodnowèrnegšj “(Kollár 1825, 203).

2 „Proč ge toto poslednj hodnowěrněgšjm? Proto, ponewádž slowo, na slow o wzatý, slow u tný, v naší reči často totéž znamená co slá wa, sla we n, sl a w ný, tak že se Slowana Slawen neb Slawian wzágemně užjwati mohau k poznačenj s la w ného : nikoli ale naopak, slá wa newyznamenáwá nikdýa nikde w našem národě rěěč, gazyk, slowo; a Slawian, Slawjn nemůže se nigakž bráti za lid gednoho slowa“(Kollár 1825, 231).

3 „Oni weždy wjce pokog nežli wognu milowali, obljbenj měli obzvláště w hospodárstvj, býwali pracowitj a skromnj lidé, milowali hudbu a weseléspěwy, a láska k náboženstwu ge každého času wyznačowala"(Kollár 1825, 203).

4 Zaujímavé je, že autor neuvádza v kategórii „cjrkewnj mužové“ (Kollár 1825, 207) meno Konštantína a Metoda, len meno „Nicetas, Patriarcha konštantinopolitanský“ (Kollár 1825, 207), ktorým sú však 
V texte Krátičká známost národu Slowanského sa formou otázok a odpovedí, teda katechetickým štýlom, ktorý využíval nemenné otázky a odpovede (v prvom vydaní textu je 28 otázok, z toho jedna, nasledujúca po 7. otázke, či rozširujúca ju na s. 204, je sprostredkovaná vo forme poznámky („poznamenánj“), teda Kollárovho návrhu na doplnenie textu, a to na s. 231), predkladajú potenciálnemu mladšiemu recipientovi poznatky zo „slovanských“, užšie a len nepriamo, slovenských, teda národných dejín.

Oproti pohanskému náboženstvu („modlařstwo“; Kollár 1825, 203) a božstvám autor vyčleňuje krestanské náboženstvo. V odpovediach na niekolko otázok („Kterého času prigali Slowané křestanské náboženstwo?, Gako se gmenowali ti mužowé, kterj ge křestili a wynaučowali?"; Kollár 1825, 204) sú sprostredkované informácie o storočí, ba i konkrétnom roku prijatia krestanského náboženstva Slovanmi, ktoré sú spájané s príchodom vierozvestcov, teda so sv. Cyrilom a Metodom: „Cyril a Metod dwa bratřj, Řeci, z mesta Tesalonichy, přišli na žádost Swatopluka a Rostislawa do Morawy a Panónie, kde křestili a Pjsma swatá na gazyk slowanský preložili“ (Kollár 1825, 204).

Zaujímavá je aj reflexia cyrilo-metodskej tradície v literárnom umení, teda v Nestorovom letopise, ktorá napovedá o radostnom prijímaní Božieho slova $\mathrm{v}$ jazyku zrozumitelnom („přirozeném") Slovanom:

Gakože mluwj geden toho času Spisowatel o této pamatné přjpadnosti?

„Wysoko plesali, prawj Nestor geden starožitný slowanský Spisowatel, wysoko plesali a radowali se Slowané, když uslyšeli weliké diwy božj we swém přirozeném gazyku“ (Kollár 1825, 204); resp. aj reflexia historicko-geografických súvislostí pri šírení krestanského náboženstva zo slovanského priestoru, teda od Slovanov k Madarom.

Od Slowanu pak kdo potom prígal křestanské náboženstwo?

Ginj sausednj národowé $k$. p. Mad’aři gegichžto krále S. Stěfana pokřestil a na wjru křestanskau obrátil S. Wogtěch, byskup Pražský a rozený Slowan (Kollár 1825, 204).

Tridsiate roky 19. storočia sú považované za obdobie stagnácie literatúry pre deti a mládež (Sliacky 2007), napriek tomu v rokoch 1834 (Djl perwý) a 1835 (Djl druhy) boli vydané Národnié zpiewanky Jána Kollára. Nimi autor nepriamo kliesnil cestu uzákoneniu spisovnej slovenčiny a zároveň ovplyvnil vzdelávanie a výchovu nastupujúcej mladej generácie.

V 1. časti diela Národnié zpiewanky čili pjsně swětské Slowáků w Uhrách gak pospolitého lidu tak $i$ wyššjch stavů, v kapitole Zpěwy historicky pamatné, pod číslom 1. a názvom Pozůstatek starowèrectwj Slováků (asi r. 989) sa nachádza duchovná (hymnická) pieseň Hospodine pomilug ny (Kollár 1834, 29; Kollár 1953, číslo piesne 81). ${ }^{5}$

Pieseň síce priamo vo veršoch neodkazuje na cyrilo-metodskú tradíciu či tému, ale v poznámke pod piesňou sa nachádza zdôvodnenie jej začlenenia medzi „národné“ spievanky.

pomenovaní dvaja patriarchovia Nikétas I. (766 - 780) a Nikétas II. Mountanes (1186 - 1189) (Vavř́nek 2011; Kiminas 2009).

5 Hospodine pomilug ny,

Jesu Christe, pomilug ny,

Ty spase wšehomira

Spasiž ny i uslyš

Hospodine, hlasy našie,

day nám wšem Hospodine

Žizn a mir w zemi:

Krles, krles, krles (Kollár 1834, 29).

6 „Hospodine pomilug ny. 'Negeden $z$ našich čtenárù se snad zadiwj: gak tato pjseň do této Zbjrky přigjti mohla? ale Slowáci ovšem magj většj práwo $k$ nj, než Čechowé. To uznal už Dobrowský, genž o této pjsni w Děgopisech české slowesnosti takto pjše: ,Der Text dieses Liedes hat mehr Aehnlichkeit mit dem alten 
Pôvod duchovnej piesne sa odvodzuje od pôsobenia vierozvestca Metoda v moravsko-panónskom priestore, čím sa nepriamo podporuje aj budovanie národného povedomia, a to v kontexte osvietenskej literatúry, podla Jána Kollára ludovej proveniencie (pozri Obrana těchto Zpiewanek proti některým předsudkům a nedorozumenjm; Kollár 1835, 490-499), do ktorej prenikali prvky či výtvory krestanskej duchovnej poézie (hymnická pieseň). A ludová slovesnost̉ sa považuje za jeden z podsystémov literatúry pre deti a mládež, ktorého žánre zodpovedali chápavosti a psychicko-mentálnym osobitostiam (Kopál 1997) potenciálneho recipienta z okruhu detí a mládeže.

Pieseň je dnes považovaná za najstaršiu českú duchovnú pieseň (pričom autorstvo sv. Vojtěcha sa považuje za možné, ale nie preukázatelné, Havránek - Hrabák 1957; Kosmova kronika česká 1972; Lehár 1990; Škarka 1949), kedže má starosloviensky pôvod, ba prenikli do nej aj prvky staročeštiny. Aj Bohuslav Tablic v druhom paragrafe s názvom Trosky starých slovenských piesní z prvého dielu Pamätí česko-slovenských básnikov alebo veršovcov, ktorí sa alebo v Uhorsku narodili alebo aspoň $v$ Uhorsku žili $(1806,1807,1809,1812)$ (Tablic 2000, 10-11) charakterizuje pieseň Hospodyne, pomiluy ny ako najstaršiu z českých piesní z 10. storočia, ktorú „údajne zložil sv. Vojtěch, druhý pražský biskup, a jej rukopis je v národnej pražskej knižnici“. Dôležitejšie však je to, že podla autora Slováci uhorskí, ktorí sa spolu s Moravanmi a Čechmi majú považovat za jeden národ, „nijaké také spevy nemajú, iba ak by sa boli azda zachovali ešte medzi pospolitým ludom zvyšky podobných starých piesní" (Tablic 2000, 10). A zmieňuje sa o piesňach Morena, Morena a Haja, dund’a, haja!, ktoré však spolu s d’alšími ludovými prejavmi z predkrestanského obdobia možno označit za kultúrnu základňu formujúcej sa staroslovienskej literatúry.

Ján Kollár v jednej z častí diela Národnié zpiewanky - Poznamenania a pojednánia $k$ II. djlu Zpiewanek (1835, 459-506) zdôrazňuje význam zapisovania historických i dalších piesní v Spievankách, teda nepriamo aj význam zápisu piesne Hospodine, pomilug ny, aj ked” „skládánie gegich nemá giné wzácnosti, ledaže za důkaz slaužiti může okusu staršjch časưw"(Kollár, 1835, 464), a načrtáva perspektívu ich využitia v kontexte literárnej histórie: „Budeli wšak někdo budaucně psáti historiu slowenského básnictwa, nesmj i takowých plodin bez powšimnutj nechati“ (Kollár $1835,464)$.

Aj v XII. kapitole (v XIII. kapitole v upravených vydaniach) Obrana těchto Zpiewanek proti některým předsudkům a nedorozumenjm Ján Kollár odmieta negatívne prijímanie Spievaniek niektorými spomedzi kňazov a zdôvodňuje nielen národný význam piesní, ale aj význam literárneho vzdelania pre ich primeranú recepciu. ${ }^{7}$

slawishen Kirchendialect, als irgend ein anderes Denkmal. Vielleicht hat es Adalbert bei seinem Aufenthalt in Ungarn (r. 989.) bei der slawischen Messe singen hören, und es seinen Böhmen von da mitgebrackt." Jos. Mladon w Histor. liter. p. 24. pjše o téže pjsni: ,Zdá se býti zůstatek slowanské liturgie, snad ze časio Bořiwogowých.' Bořiwog ale přigal (r. 879.) křest, a s nim i náboženstwo, obřady a zpěwy od Methoda blahozwěsta morawsko-slovenského čili panonského; na každý tedy přjpad gest naše wlast kolébkau této pjsně. We starodávných nábožných pjsněch Slováků nalezagj se geště mnohé, této pjsni podobné, w nichž se, právě tak gak tu, Kyrieeleison na konec werše přiwěšuge a zpjwá. Accusativ Ny, pomilug ny, mjsto nás, nacházj se a užjwá u Slováků posawad, negen w pjsni Morena, kde též stogj, ne za ny'ale i w obecném životě. Pokračowatel Cosmasůw při r. 1260. gmenuge gi , hymnum a S. Adalberto editum. Slovo editum neznačj pưvodce ale gen wydavatele a přinášitele od ginud. Podle nyněgšjho zpi̊sobu mluvenj ta pjseň se wykládá: ,Hospodine smilug se nad nami, Jesu Kriste smilug se nad nami. Ty spasiteli wšeho světa, spasiž nas i uslyš Pane hlasy naše. Dey nám wšem pane Úrodu a pokog w zemi “ (Kollár 1834, 436-437).

7 „Kýžby tuto wýše wygádřenau wysokau cenu národnjch Zpěwů, kýžby ona, na str. 465 přiwedená slowa pana Thibauta: ,Ich halte das Studium der Volkslieder für Etwas höchst Bedeutendes' powážili ti slowenštj kněži, kleřj se, saukromnè i weřegně, ustně i pjsebně, bud’ z národnj neumělosti, bud'z mysthické zlerozumené pobožnosti, toto naše předsewzetj tak nádherně a urážliwě odsuzowati a zlehčowati nestyděli, a kteřjby, 
V roku 1863 vznikla Matica slovenská, ktorá sa v prvom paragrafe svojich stanov definuje ako „jednota milovníkov národa a života slovenského“, pričom svoj ciel” charakterizuje takto: „v členoch slovenského národa mravnú a umnú vzdelanost' budit', rozširovat' a utvrdzovat; slovenskú literatúru a krásne umenia pestovat' a podporovat a tým i hmotný dobrobyt slovenského národa napomáhat' a na jeho zvelebení pracovat" (Stanovy Matice slovenskej z r. 1862, Botto 1923). V matičných rokoch (1863 - 1875) sa prebúdza záujem aj o literatúru pre deti a mládež. Už v roku 1864 vychádza vdaka Matici slovenskej prvý diel a o rok neskôr, v roku 1865, aj druhý diel Slovenskej čítanky. Čítanka je určená pre nižšie, ako aj vyššie triedy stredných škôl a jej zostavovatelom sa stal banskobystrický profesor Emil Černý.

Ako uvádza Július Lomenčík $(2016,6)$, Emil Černý spracoval čítanku „na podnet biskupa Štefana Moysesa a riaditela banskobystrického gymnázia Martina Čulena“, člena výboru Matice slovenskej.

Slovenskou čítankou Černý priniesol do kontextu detskej literatúry (texty zo slovenského osvietenského klasicizmu a preromantickej literatúry, dopl. M. P.) aj beletristické texty romantickej generácie, teda esteticky účinný model intencionálnej prózy, ktorý sa konfrontoval s dobovou intencionálnou literatúrou pre deti založenou na didaktických princípoch (Sliacky 2007, 31-32).

Emil Černý už v 1. diele čítanky vedla seba zarad’uje tematicky príbuzné texty, medzi nimi sa nachádzajú Životopis sv. Cyrilla a Methoda od Jána Hollého a báseň Miloslava Pohronského Na deň sv. Cyrilla a Methoda.

Životopis sv. Cyrilla a Methoda ako žáner literárnej tvorby (beletristické biografické žánre - literárny životopis, Liba 1995), ktorý volí Ján Hollý, aj ked’ je dodatočne Emilom Černým zaradený medzi žánre určené na literárne vzdelávanie, sčasti nadväzuje na legendy o Konštantínovi a Metodovi, vyznačujúcimi sa aj životopisnými znakmi. Avšak autor na rozdiel od legendy opisuje život vierozvestcov a ich pôsobenie na území Vel'kej Moravy, či v moravsko-panónskom priestore bez toho, aby im prirad’oval výnimočné vlastnosti či zobrazoval ich zázračné skutky. Zameriava sa na zobrazenie udalostí, zviazaných so životmi Konštantína a Metoda v logicko-časovej následnosti: Rastislavova prosba, adresovaná gréckemu cisárovi Michalovi, o „učitelov, ktorí by vynaučovali Slovákov vo viere krestanskej a prekladali im písmo sväté" (Hollý 1864, 41), prijatie bratov na „Morave a Slovensku“ (Hollý 1864, 41), vyučovacia činnost’ a zápas s „modlami“, prekladatelská a organizačná práca, ktorou viedli na „cestu spasenia všetkých Slovákov“ (Hollý 1864, 42), cesta bratov do Ríma a ich vysvätenie za biskupov pápežom Hadriánom. Pokračuje rozprávaním o Konštantínovom vstupe do kláštora, o prijatí mena Cyrill až po jeho smrt'. Rozpráva o Metodovom ustanovení za arcibiskupa a jeho zápase s nemeckými kňazmi, či obhajobe slovanskej liturgie v Ríme, aby vypovedal o Metodovej smrti a d’alšom vývoji situácie v moravsko-panónskom priestore, teda o vytláčaní slovanskej liturgie a „vymieraní“ slovanského obradu.

Zaujímavým odbočením či doplnením opisu životov Konštantína a Metoda sú posledné dva odseky textu, ktorými sa dosahuje skôr napĺňanie poznávacej funkcie textu určeného pre mladšieho recipienta. Autor v nich sprostredkuje informácie o vytvorení slovanského písma Konštantínom, pričom nespomína hlaholiku, len cyriliku (a jej novšiu verziu, ktorou je azbuka) pomenovanú podla Konštantínovho kláštorného mena, obsahujúcu či doplnenú o také znaky hlások, ktoré neboli ani v gréckej, ani v latinskej abecede zastúpené. Zároveň podáva informácie o staroslovanskej reči ako reči prekladov Písma, a preto ju označuje za cirkevnú reč, ktorá „nebola matkou všetkých ostatních slovanských nárečí, a jednej zo slovanských nárečí, ale len sestrou tak, jako sú teraz reč ruská, srbsko-chorvátska, slovinská, novobulharská, naša slovenská, česká, polská, lužicko-srbská jedna druhej sestrami jednoho jazyka slovanského. Bola ona nárečím starobulharským“ (Hollý 1864, 43).

kdyby bylo možné, wšecky národnj pjsně, hry, starozwyky lidu, snad w lyžici wody utopili, poněwadž oni sami odnárodnèni gsauce, takowéto poklady cjtiti a ctjti w stawu negsau“" (Kollár 1835, 490). 
Hollého spôsob zobrazenia Konštantína a Metoda je výrazom pomerne objektívneho zaznamenávania dejov zo života bratov na území Vel'kej Moravy, o čom svedčí radenie udalostí v logicko-chronologickej následnosti (od príchodu až po smrt’ a doznievanie výsledkov ich činnosti), ale je aj vyjadrením jeho subjektívneho postoja k vierozvestcom, ktorý sa „zrkadlí" v prejave vd’čnosti za ich prítomnost' v priestore Velkej Moravy (v texte sú udalosti zo života vierozvestcov ohraničené rokmi 863 až 899). Použité jazykové prostriedky, teda aj umelecký jazyk (epitetá a inverzie: král' državy velkomoravskej; $k$ cisárovi gréckemu; vo viere krestanskej; písmo sväté; pre podivnú učenost' jeho; s vel'kou vd'ačnostou; vel'kou radostou naplnený a pod., parantézy: Rastislav, král'državy (mocnárstva) vel'komoravskej; Konštantína, nazvaného mudrcom pre podivnú učenost' jeho, a brata jeho Methoda, rodilých zo Solúna;Viching, biskup nitriansky, rodom Nemec a pod., básnické trópy, medzi nimi metafory, metonymie, synekdochy a pod.: by vynaučovali Slovákov vo viere krestanskej a prekladali im písmo sväté; modly porážali; na cestu spasenia všetkých Slovákov viedli; upadnúc do nemoci; prekážal pohodlnostam kñazov; uvádza lud do bludu; obsiahol slobodu; vytískal obrady slovanské; vymieral i slovanský obrad a pod.) totiž naznačujú subjektivizáciu štýlu a snahu pozitívne zhodnocovat činnost' vierozvestcov z pozície toho, kto je „čast’ za celok“ dedičom cyrilo-metodskej tradície, reči a písma, ale aj krestanského náboženstva a vzdelanosti.

V deviatich strofách oslavnej básne Na deň sv. Cyrilla a Methoda (5. julia.) ${ }^{8}$, napísanej pri príležitosti sviatku sv. Cyrila a Metoda, ktorý sa oslavuje 5. júla a je spojený so symbolickým (pravdepodobne, rok pred vydaním čítanky, tisícim) výročím príchodu Cyrila a Metoda na Vel'kú Moravu

8 Milo ústa spevochtivé

znejú ludu našeho,

ked'velebí milostivé

dary Boha večného.

O národe, spievaj $k$ sláve

Cyrilla, Methoda dnes;

vzdaj im - čo im sluši práve -

chválu vrúcnu, sbožný ples.

Hla! ich slovom Parom padá,

Svätovid sa rúca v zem,

mizne Morenina vláda,

koniec je už žertvám všem.

A z hrobu pohanskej Slávy

vystupuje nová žiar;

je to obraz boži praví,

je to církve svätá tvár.

Na moravskom Velehrade

i na Nitre kríž sa pne,

po milom Slovensku všade

sláva božia k nebu znie.

Cyrille a Methodeju,

svätí blahozvestovia!

dnes Vám vdaky $z$ srdca lejú

Vaši pokrstencovia. 
v roku 863, reflektuje lyrický subjekt situáciu osláv, ba sám oslavuje vierozvestcov. Oslavný ráz tematizovanej sviatočnej situácie vyjadruje básnickými prostriedkami, synekdochami pars pro toto („čast’ za celok“ - „Milo ústa spevochtivé, „Vám vd’aky z srdca lejú"), metaforami („ústa spevochtivé / znejü“, „z srdca lejü“, „zasiaty Vami zárod“, „zkvitol mu v čas blažený“...) či synekdochou totum pro parte („celok za čast" - „O národe, spievaj k sláve“, „po milom Slovensku všade / sláva božia k nebu znie").

Básnický subjekt vyzýva k oslave Boha a blahozvestcov („spievaj k sláve / Cyrilla, Methoda dnes; / vzdaj im - čo im sluší práve - / chválu vrúcnu, sbožný ples"). Vierozvestcovia sú stvárnení ako tí, ktorí sa „slovom“ konfrontujú s pohanským náboženstvom a jeho božstvami („ich slovom Parom padá, Svätovid sa rúca v zem, / mizne Morenina vláda“). Ešte markantnejšie sa oproti pohanstvu situuje krestanské náboženstvo v d’alšej strofe, ked’ sa oproti tme (symbol hrobu) situuje svetlo (symbol žiaru), „obraz boží pravy“", „církve svätá tvár“, oproti pohanstvu sa presadzuje pravý Boh a Cirkev, usporiadané spoločenstvo veriacich založené Ježišom Kristom.

Smrt’ pohanskej Slávy ako slovanského božstva evokuje nové svetlo krestanského učenia rozširovaného $\mathrm{v}$ reči zrozumitelnej ludu, $\mathrm{v}$ reči slovenského národa a v jeho prostredí. Význam motívu slovenského národa sa intenzifikuje v súvislosti s dobovým nazeraním na („opustený, zbiedeny“") národ, ktoré vychádza z látkovej skutočnosti a predznamená potrebu vzdelávat Slovákov a poskytnút im vhodné čítanky.

Symbol kríža ako symbol prieniku neba a zeme, priestoru a času, ako krestanský symbol, ktorý je obrazom Kristovho utrpenia a jeho vítazstva (Becker 2002, 136), sa spomína vo dvojverší „Na moravskom Velehrade / i na Nitre kríž sa pne“, čím sa v podobe predľžených „vertikál“ orientovaných $\mathrm{k}$ nebu (Velehrad/Nitra, hrad/sídlo $\rightarrow$ kríže) stáva znamením krestanstva preneseného na „horizontálu“ v priestore Velkej Moravy. A tá je dejinne spojená so slovenskou (a českou) štátnostou, ako aj s prijatím krestanskej viery slovenským národom a zachovávaním kontinuity vo viere („Otcovia Vás velebili / slyšte i nás vd’ačný hlas;“), čo sa prejaví oslavou Boha slovenským spevom, či prosbami adresovanými Bohu a vierozvestcom, a tematizuje sa aj v dalších dvojveršiach „po milom Slovensku všade / sláva božia k nebu znie“, „Pána, v ktorom sbožne žili, / proste za nás každý čas!“, „Orodujte za náš národ“.

Intenzita väzby milého Slovenska, celok za čast', teda Slovákov zo všetkých častí krajiny, na slovanských svätých blahozvestcov vyplýva $\mathrm{z}$ „daru krstu“, čo básnický subjekt vyjadrí v dakovnom dvojverší „dnes Vám vd’aky z srdca lejú / Vaši pokrstencovia“, ale aj v prosbách adresovaných vierozvestcom: „by zasiaty Vami zárod / zkvitol mu v čas blažený.“ Zárodok (začiatok) sa stáva predpokladom kvetu či kvitnutia, metaforicky vyjadrujúceho pozitívnu (blaženost', „pokoj lud’om v zemskej rísii, / pokoj s tebou, národe!") perspektívu ludí, užšie, slovenského národa v pozemskom

Otcovia Vás velebili:

slyšte i nás vdačný hlas;

Pána, v ktorom sbožne žili,

proste za nás každý čas!

Orodujte za náš národ

opustený, zbiedený,

by zasiaty Vami zárod

zkvitol mu v čas blažený.

Sláva, čest' Vám tam na výši,

Cyrille náś, Methode!

pokoj ludom v zemskej ríši,

pokoj s tebou, národe! (Pohronský 1864, 43-44). 
kontexte. Predpokladom formovania perspektívy ludu sa však stáva jeho začleňovanie sa širšieho, duchovného rámca - reprezentovaného biblickým motívom pokoja a oslavou sv. Cyrila a Metoda („Sláva, čest' Vám tam na výši, / Cyrille náš, Methode!“).

Pohronského spôsob zobrazenia Cyrila a Metoda je výrazom subjektívnejšieho postoja, ovplyvneného vierou a vedomím o zachovávaní cyrilo-metodského odkazu v slovenskom prostredí. Básnik vyjadruje subjektívny postoj aj použitými umeleckými jazykovými prostriedkami so zámerom oslávit’ slovanských bratov prostredníctvom pomenovania ich zástoja v slovenských dejinách a prínosu pre Slovákov.

Zápis piesne Nitra, milá Nitra v diele Národnié zpiewanky, v kapitole Zpěwy historicky pamatné, spája Ján Kollár $(1834,29)$ s menami Ondreja Novotu (Ondřeg Nowota) a Ondreja Bošániho (Ond. Bošáni).

V rovnakej piesni zo Slovenskej čítanky v porovnaní s textom zapísaným v Kollárovom diele Národnié zpiewanky čili pjsně swětské Slowáků w Uhrách gak pospolitého lidu tak $i$ wyššjch stavů (1834) nedochádza k významovým posunom, ale len k posunom na jazykovej rovine textu pri jeho prepise $\mathrm{v}$ súlade s dobovým úzom ( $w \rightarrow v$ : wysoká, $w$ ktorých, kwitla, slowenská, wšeckých, hlawa, Wisla, Morawa, Swatopluka, panowala, swaté, Methodowo, slowo, twoga, sláwa; $a \rightarrow a ̈:$ na teba, swaté, Swatopluka, swět; $j \rightarrow$ ilí: musjm, našjm, ležj, bežj; ě $\rightarrow e:$ někdy, město, swět; $c \rightarrow t:$ wšeckých; $g \rightarrow$ $j:$ kragin, Dunag, geho, twoga; $l \rightarrow l:$ krála; $u \rightarrow l:$ kázau; é $\rightarrow e:$ božié; uo $\rightarrow$ ô: tuoni; á $\rightarrow$ a: meniá; Wčilek $\rightarrow$ Teraz).

V poznámke k historickým piesňam zo s. 29 (1834, 437-438), medzi ktoré Kollár radí aj Nitru, tiež uvádza, že z historického hladiska ide o „najpamätnejšie“ piesne, aj ked” niektoré z nich sa „zdagj býti plodem vzdělanosti ale už znárodnělým“.

Podla poznámky Eugena Paulínyho 1953) vo vydaní diela Národnie spievanky 1, v Spevoch historicky pamätných, V. Chaloupecký (Prúdy IX, 1925) pokladá túto pieseň za skladbu Sama Chalupku, aj ked’ pieseň je staršia, pretože Vojtech Šimko (umrel 1827) ju má vo svojich rukopisoch a zložil k nej siedmu strofu (porov. Dr. Celestín Lepáček, Vojtech Šimko, spisovatel'Bernolákovej školy 1942, 121n.).

Národnú pieseň Nitra, milá Nitra (Národná pieseň.) $)^{9}$ nájdeme aj v Slovenskej čítanke Emila Černého $(1866,46)$. Pieseň sa tematicky viaže na zástoj Nitry v slovenských dejinách, ba aj na cyrilo-metodský odkaz spojený s menom vierozvestca Metoda.

9 Nitra milá, Nitra, ty vysoká Nitra!

kdeže sú té časy, v ktorých si ty kvitla?

Nitra milá, Nitra, ty slovenská mati!

čo pozrem na tebä, musím zaplakati.

Ty si bola nekdy všetkých krajín hlava,

$v$ ktorých tečie Dunaj, Visla i Morava.

Ty si bola bydlo krála Svätopluka,

ked' tu panovala jeho mocná ruka.

Ty si bola sväté mesto Methodovo,

ked' tu našim otcom kázal božie slovo.

Teraz tvoja sláva $v$ tôni skrytá leží:

tak sa časy menia, tak tento svet beží (Černý 1866, 46). 
Básnický subjekt v piesni apostrofuje mesto, s ktorým sú spojené počiatky slovenských dejín, či ktorého dejiny sa odvíjajú už od vel'komoravských čias. Mesto je pritom zobrazené prostredníctvom básnických prívlastkov ako „Nitra milä“, „vysoká Nitra“, teda ako miesto, ku ktorému má básnický subjekt citový vztah a ktoré svojou výškou (stavieb - už v rokoch 829 - 833 dal Pribina vysvätit krestanský kostol v Nitre) presahuje očakávanie básnického subjektu, ba, vyjadrené metaforicky, má už za sebou „časy, v ktorých [si ty, M. P.] kvitla“, teda rozkvetu.

Vo vztahu k slovenským dejinám a vo väzbe na cyrilo-metodskú tradíciu zobrazuje Nitru ako antropomorfizovanú slovenskú matku, ktorá pri vizuálnej recepcii vzbudzuje smútok, navonok vyjadrený plačom. Nitra je konfrontovaná so svojou minulostou prostredníctvom symbolov a synekdoch („Ty si bola nekdy všetkých krajín hlava“, „Ty si bola bydlo krála Svätopluka“, „Ty si bola sväté mesto Methodovo").

Básnický subjekt pritom zdôrazňuje velkomoravskú aj krestanskú tradíciu, zviazanú s priestorom svetského kniežata („bydlo krála Svätopluka“) i duchovného vodcu („sväté mesto Methodovo“), ktorým pripisuje vysokú hodnotu prostredníctvom synekdoch „mocná ruka“, „našim otcom kázal božie slovo“. Kontrastom sa umocňuje rozdiel medzi časmi vtedy a teraz, teda medzi slávnou minulostou a terajším stavom, ked’ sa na minulost’ zabudlo, čo sa vyjadrí metaforicky - „tvoja sláva $v$ tôni skrytá leží. Avšak nemožno uvažovat’ o nemennej situácii, pretože lexikalizované metafory naznačujú dynamickost', nie statickost' dejov.

Spôsob zobrazenia vierozvestca Metoda je subjektívnejším zobrazením osobnosti, ktorej básnický subjekt privlastňuje Nitru, stávajúcu sa svätým mestom, pretože zastupuje spojenie medzi Bohom a lud’mi - „našim otcom kázal božie slovo“. Básnický subjekt vyjadruje subjektívny postoj $\mathrm{k}$ Nitre a sprostredkovane aj $\mathrm{k}$ vierozvestcovi Metodovi so zámerom oslávit Nitru a jej slávnu minulost', kedže bola miestom pôsobenia Metoda v kontexte krestanských slovenských dejín.

Kultúrnym odkazom vierozvestcov Cyrila a Metoda, ktorí pôsobili na Velkej Morave, sa inšpirovala aj literatúra pre deti a mládež v predumeleckom období. Vo vybraných etapách jej literárnohistorického vývinu (osvietenská literatúra pre deti a mládež $\rightarrow$ literatúra pre deti a mládež v matičných rokoch) sme identifikovali niekol'ko textov z klúčových diel detskej literatúry. Vybrané texty (Krátičká známost vlasti národu Slowanského, Hospodine pomilug ny), ktoré redigoval Ján Kollár, revitalizujú cyrilo-metodský odkaz bud' sprostredkovaním informácií o prijatí krestanského náboženstva Slovanmi v jazyku zrozumitelnom ludu od Cyrila a Metoda, alebo odvodzovaním pôvodu najstaršej duchovnej piesne od pôsobenia Metoda v moravsko-panónskom priestore a jej zarad’ovaním do kultúrnej základne formujúcej sa staroslovienskej literatúry spolu s d’alšími ludovými prejavmi.

V matičných rokoch v kontexte literatúry pre deti a mládež vychádza Černého dielo (Slovenská čitanka), ktoré obsahuje niekolko textov ovplyvnených cyrilo-metodským odkazom (Životopis sv. Cyrilla a Methoda, Na deň sv. Cyrilla a Methoda, Nitra milá, Nitra). Texty nielenže oživujú odkaz vierozvestcov pripomínaním si udalosti ich príchodu na Velkú Moravu a zdôrazňovaním významu ich pôsobenia pre slovenský národ, „dediča“ tradície (náboženstva a vzdelanosti), ale báseň a národná pieseň sú aj oslavou slávnej minulosti a odkazu vierozvestcov.

\section{REFERENCES}

Becker, Udo. 2002. Slovník symbolů. Praha.

Botto, Július. 1923. Dejiny Matice Slovenskej. (1863 - 1875). Turčiansky Sv. Martin.

Brtán̆, Rudo. 2000. Bohuslav Tablic (1769 - 1832). In Tablic, Bohuslav. Pamäti česko-slovenských básnikov alebo veršovcov, ktorí sa alebo v Uhorsku narodili, alebo aspoň v Uhorsku žili (1806, 1807, 1809, 1812). Bratislava, 217-250. 
Brtáň, Rudo. 1970. Pri prameňoch slovenskej obrodeneckej literatúry. Bratislava, 28, 119-120.

Černý, Emil. 1866. Slovenská čítanka. Pre gymnasia. Diel I. Sostavil Emil Černý. Druhé opravené vydanie. V Baňskej Bystrici.

Fordinálová, Eva. 2009. Staršia slovenská literatúra. Trnava.

Havránek, Bohuslav - Hrabák, Josef (eds.). 1957. Výbor z české literatury od počátků po dobu Husovu. Praha.

Ivanštyšinová, Tatiana - Podolan, Peter - Viršinská, Miriam. 2013. Básnik a mesto. Viedenské roky Jána Kollára. Bratislava.

Kiminas, Demetrius. 2009. The Ecumenical Patriarchate. San Bernadino, CA, 30-51.

Kollár, Ján. 1825. Čítanka anebo Kniha k čítaní pro mládež ve školách slovanských v městech a v dědinách. Budín.

Kollár, Ján. 1834. Národnié zpiewanky čili Pjsně swětské Slowáků w Uhrách gak pospolitého lidu tak i wyššjch stawů, sebrané od mnohých, w pořádek uwedené, wyswětlenjmi opatřené a wydané od Jana Kollára. Djl perwý. W Budjně w Král. universické tiskárně.

Kollár, Ján. 1835. Národnié zpiewanky čili Pjsně swětské Slowáků w Uhrách gak pospolitého lidu tak i wyššjch stawů, sebrané od mnohých, w pořádek uwedené, wyswětlenjmi opatřené a wydané od Jana Kollára. Djl druhy. W Budjně w Král. universické tiskárně.

Kollár, Ján. 1953. Národnie spievanky I. diel. Eugen Pauliny pripravil text a doplnil poznámkami. Bratislava.

Kollár, Ján. 1972. Pamäti z mladších rokov života. Ed. a prel. K. Rosenbaum a K. Goláň. Bratislava. Kosmova kronika česká. 1972. Přel. K. Hrdina a M. Bláhová. Praha.

Kopál, Ján. 1997. Próza a poézia pre mládež. Teória/poetológia. Nitra.

Lehár, Jan (ed.). 1990. Česká středověká lyrika. Praha.

Liba, Peter. 1995. Dostredivé priestory literatúry. Nitra.

Lomenčík, Július. 2016. Slovenčina na slovenskom evanjelickom a. v. patronátnom gymnáziu v Revúcej - Inšpirácie a pdonety pre súčasné vyučovanie slovenského jazyka a literatúry (2. čast'). In Slovenčinár 3/2, 6-18.

Podolan, Peter. 2011. Krátičká známost vlasti národu Slowanského. In Podolan, Peter (ed.). Štúdie k jubileu Pavla Jozefa Šafárika. In Historia nova II, 39-58.

Ratio educationis 1777 a 1806. 1988. Preložili J. Mikleš, M. Novacká. Bratislava.

Sliacky, Ondrej. 2007. Dejiny slovenskej literatúry pre deti a mládež do roku 1960. Bratislava.

Škarka, Antonín. 1949. Nejstarší česká duchovní lyrika. Praha.

Tablic, Bohuslav. 2000. Pamäti česko-slovenských básnikov alebo veršovcov, ktorí sa alebo v Uhorsku narodili, alebo aspoň v Uhorsku žili $(1806,1807,1809,1812)$. Bratislava.

Vavř́nek, Vladimír. 2011. Encyklopedie Byzance. Praha.

PaedDr. Martina Petríková, PhD.

Slovak Literature and Literary Studies

Institute of Slovak and Media Studies

Faculty of Arts

University of Presov

Ul. 17. novembra č. 1

Prešov 08001

Slovakia

martina.petrikova@unipo.sk 